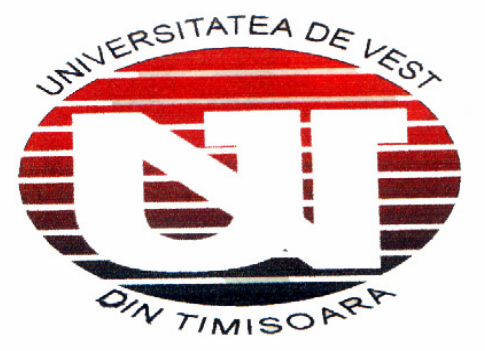

SISEC Discussion Papers
WEST UNIVERSITY OF TIMIŞOARA Jean Monnet European Centre of Excellence

Timişoara www.migratie.ro

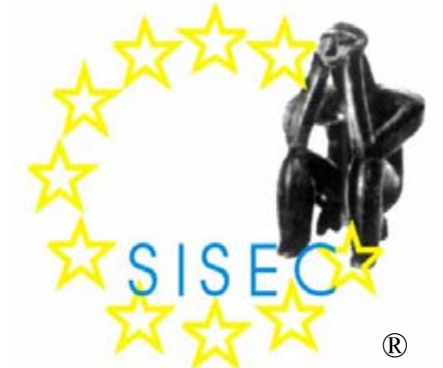

(R)

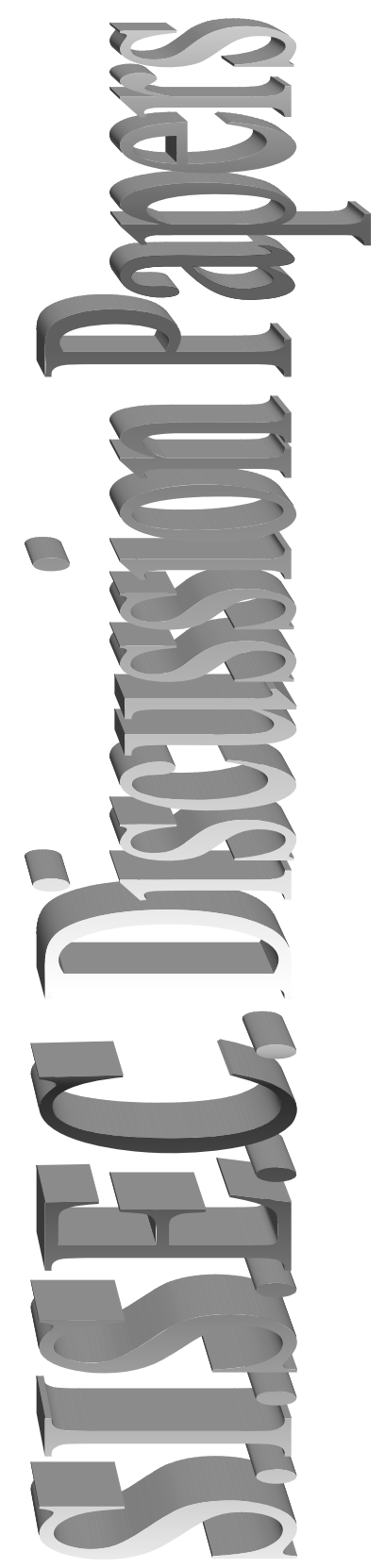

Vol.7 No.2, November 2008

Romania and the New Economy of Migration: Costs, Decision, Networks, Development

Grigore SILAȘI

Ovidiu Laurian SIMINA 
SISEC Discussion Papers is edited since 2002 by the Jean Monnet European Centre of Excellence within the West University of Timişoara, Timişoara - Romania, and is based on a project of the former School of High Comparative European Studies (SISEC) - the first Romanian academic post-graduate school to award M.A. in High European Studies, with the competences of "Expert in European Affairs" (SISEC existed between 1995 and 2006).

Director: Prof. Grigore SILAȘI, PhD, Jean Monnet Professor

Editor: Ovidiu Laurian SIMINA, LLB, MA, PhD Candidate

Address: Universitatea de Vest din Timişoara, Centrul European de Excelență Jean Monnet, Bd. Pârvan nr.4, room 513, 300223 Timişoara, Timiş, Romania

Telephone: 0040722664.130 / Fax: 0040356814.937

Web page: www.migratie.ro; E-mail: sisec@migratie.ro

SISEC Discussion Papers, Vol. 7, No.2, November 2008, Timişoara: SISEC

ISSN 1841-7523

Silaşi, Grigore and Simina, Ovidiu Laurian: Romania and the New Economy of Migration: Costs, Decision, Networks, Development

Please specify the source in case of quotation. The comments and references are welcomed. Any opinions expressed here are those of the author(s) of the papers included in the journal and do not commit either the SISEC or the national/institutional authorities concerned. SISEC Discussion Papers often represent preliminary work and are circulated to encourage discussion. Citation of such a paper should account for its provisional character.

C) SISEC, Timişoara, 2002-2008

(B) SISEC is registered mark with OSIM no.86162/24.05.2007, Bucharest - Romania

The paper was prepared for and presented at the international workshop "România pe coordonate europene" [Romania, on European Paths], panel „Economic sciencs - Economy and European Integration", held on 21-22 November 2008 at Universitatea Europeană

Drăgan din Lugoj, Lujoj, Timiş, Romania. The authors thank to a peer reviewer who commented on a previous version of the paper. 


\title{
ROMANIA AND THE NEW ECONOMY OF MIGRATION: COSTS, DECISION, NETWORKS, DEVELOPMENT*
}

\author{
Grigore SILAŞI $^{1}$ and Ovidiu Laurian SIMINA ${ }^{2 \ddagger}$
}

\begin{abstract}
In some earlier studies, as a response to the media debate during the hot summer of 2006, regarding Romania's emigration as following the accession to the EU, we were saying that the fear of mass migration from Romania was not justified. Romania is not only a gateway for the East-West international migration (like Portugal, Spain, Italy and Greece for the South-North direction), but a labour market in need of workers. Nowadays, almost two years after January $1^{\text {st }}, 2007$, the facts prove our prediction as being true. While a big part of the labour force is already migrated, mostly to the SE Europe (some $2.5 \mathrm{~m}$ workers are cited to be abroad, with both legal and illegal/irregular status, even before the EU enlargement), the Romanian companies could not find local workers to use them in order to benefit from the money inflow targeting Romania in the light of its new membership to the European Union (foreign investments and European post accession funds). Instead of increasing the salaries, the local employers rather prefer to 'import' workers from poorer countries (Moldavians, Chinese, Ukrainians and others who still accept a lower wage as compared to the medium wage in Romania, but bigger enough as compared to those from their countries of origin).
\end{abstract}

${ }^{1}$ Jean Monnet Professor, Jean Monnet European Centre of Excellence, West University of Timisoara, Romania

${ }^{2} \mathrm{PhD}$ Student, Faculty of Economic Sciences, West University of Timisoara, Romania

\$ Correspondence author: OP1 - CP372, 010145 Bucharest 1, Romania; Mobile: +40-722-664.130; Fax: +40-356-814.937; E-mail: ovidiu.simina@migratie.ro, Web: www.migratie.ro

Keywords: labour migration, labour market distortions, South-Eastern Europe Syndrome, network effect, decision making, motivation, need for esteem

JEL classification: F22, F24, J11, J22, J61, J70, O15, O52, R23

\section{Introduction}

We believe that our paper bring an important contribution at the debates on European migration, having in mind the issues we propose. We chose Romania as case study because we consider it as the best example for proving that the history is cycling and we do not need to reinvent the wheel ${ }^{l}$ : we could analyse the migration phenomena at a small scale and to extend the previsions to the European Union as a whole. Romania could be seen as an experimental country and a laboratory for analysing the policies and links between migration and development. Even if the population decreased year after year in the last decade $^{2}$, Romania is a big country from the demographical point of view, the second large country in the Central and Eastern Europe after Poland and the seventh country among the 27 Member States within the EU. Romania is an important source for

\footnotetext{
* The paper is part of a study dedicated to distortions the Romanian labour market faces beyond the EU enlargement. The first version of the study was published as Romania and the Syndrome of the South-Eastern Europe in SISEC Discussion Papers, Vol.5 No.7, December 2006, West University of Timisoara. We thank an anonymous peer reviewer who commented on this version.

${ }^{1}$ To understand the reasons why it is no need to discover what was already happened, was said or even wrote in the field of migration, see van Krieken (2004).

2 According to the 2002 Population and Housing Census data, Romania had 21.6 million inhabitants, being the ninth among the European countries (21,680,974 inhabitants as of March 18, 2002, while the 1992 Census registered 22,810,035 inhabitants, a decrease of 1.1 million people during a period of ten years, an average decline of $-0.5 \%$ per annum, due to the lower birth rate and negative balance of emigration). Source: Census of Population and Dwellings, March 18-27, 2002, Romanian National Institute of Statistics (INS); available at: http://www.insse.ro/cms/files/RPL2002INS/index_eng.htm
} 
economical migration. Being a borderline country for European Union, it is a transit space for migration flows too. From an important source for European migration in the last decade, Romania tends to become a target for labour migration from non-EU countries. Taking into account the fact that $45 \%$ of the Romanian population [still] lives in rural areas $^{3}$, where the rural workers could hardly find jobs nowadays (the males are agriculture workers, while the females are home-keepers), Romania used to act as a major actor both on the seasonal agricultural market and on the illegal prostitution market within the European Union, even before the enlargement. People from rural areas or with an agricultural background have a higher propensity to migrate (they may accept easily the so-called 'dirty' or 'degrading' activities and hard jobs). Analyzing the dynamics and structural mutations in Romania for the period 1977-2002, at the level of the major groups of occupations, the officials of the Romanian Ministry of Labour, Social Solidarity and Family have mentioned that,

'in the context of the general decline in the employment population, there was a
substantial decrease in the size of the groups; "skilled workers in agriculture, forestry
and fishery" (of 1559.4 thousand persons) and "skilled workers" (a group which
includes generically, according to the 2002 classification both "craftsmen and skilled
workers in handicrafts, in setting and maintaining machines and equipment" and
"machine and equipment operators and machine, equipments and other products fitters"
which decreased by 1553.9 thousand persons). The size of the group of "unskilled
workers" also decreased by 403.1 thousand persons) and so did the group of
technicians and related workers' (by 106.7 thousand persons)' (MMSSF 2006).

In the same time, Romania was changing the status of accession country which still implements the European acquis into Member State of the European Union; nowadays Romania tries to build proper post-accession strategies in order to benefit from the experiences of the previous waves of enlargement, to apply the implemented pieces of legislation and to continue to reform the economy. The movement of workers from Romania to the other member states is now a form of 'mobility within the European Union' and it is no more 'European migration'.

Romania is not only a source of emigrants and a gateway for East-West international migration (in the same way likes Portugal, Spain, Italy and Greece for the South-North direction), but a labour market in need of workers. Romania faces new challenges. With a labour market already confronted with distortions, Romania is twice more tempting for migrant workers' flows. As result of Romanians emigration after 2002, remittances have sustained the economic development of the country in the last years (remittances' inflow have doubled the FDI last years; unfortunately, the remittances are mostly seen as compensatory measures for helping the family for bad economy or bad luck, not generally acting as source of capital for economic development). We consider that Romania benefits from migration on short term, but needs to 'import' labour force in order to maintain the present development trend.

During our research, we did comparative analysis and a wide, complex approach of the problem in discussion. We studied the experience of countries that accessed to the European Union in the previous waves of accession, to compare the evolution of migration phenomena from that period with the migration of the CEE countries within the last decade. Some studies carried out before the 2004 accession expressed the aware of the mass migration from the eight CEE countries (so-called A8 countries) to the EU15 Member States as following the date of May $1^{\text {st }}, 2004$. The situation is quite different that it was forecasted some years ago. With the exception of the case of Great Britain (one of the three states which allowed free movement of labours from the A8 states), the number of migrants is much less significant than has been portrayed in much of the media. The experience of previous enlargements of the European Union shows that initial scepticism and fear

\footnotetext{
${ }^{3}$ Almost half of the Romanian population lives in rural areas: $45.1 \%$ on July 2005 (according to the Statistical Yearbook 2006, Chapter 2. 'Population', Graph. 2.G2), as compared to $47.3 \%$ in 2002 and $45.7 \%$ in 1992 (Census of Population and Dwellings 2002, Vol.5, Population, Households and Dwellings, Structure of population by areas, Graph. 3), Source: National Institute of Statistics
} 
of being "flooded" by migrants from the new members, with resulting attempts to restrict migration, have been unfounded. At the present, after four years of membership with the EU of the A8 countries, the figures shows that Poland was the major "threat" for the EU labour market and the welfare system at a whole, especially targeting the UK, in the condition that UK has directly attracted the Polish workers ${ }^{4}$.

Due to the lack of data and of scientific research as regarding the effects (both financial and non financial) of migration and of remittances on the Romanian economy, the scientists and decision makers could hardly design economic policies to manage the migration issues: there are no migration trends available, as resulted from generally certified data $^{5}$, nor predictions beyond the Romania's accession to the European Union ${ }^{6}$. According to our observations, we consider that Romanian labour market faces specifics phenomena, distortions, and some problems and difficulties occur as following the 2007 accession to the EU. In our research we use the theory of distortions of the labour market and the 'new' economy of migration. The migration decision is taken after the would-be migrant analyse for himself the costs and benefits of migration (regardless of its form, legal or illegal). We used microeconomic analysis on the basis of functions of utility (maximisation of utility of migration), costs (minimisation of costs incurred, from the point of economic and social costs, and maximisation of benefits; the cost of opportunity). For data processing, we used synthesis (international press survey and synthesis of the major theories regarding the international migration, benefits, remittances and development), classification, static and dynamic comparative analysis, induction and deduction.

\section{The new economy of migration}

The economic analysis of migrations deals, mainly, with two problems: why people migrate and what the consequences both for host countries as well for origin countries concerning the functioning mechanism of labour market are. The costs and benefits for the migrant himself are not less important. The migration decision refers to a plurality of motives and causes, and generally is a result of a cost-benefit analysis, influenced by negative and positive factors (pushpull). We do not intent to summarise the all main theories of migration, having in mind there are largely known and extensively debated. We analyse the decision making process for Romanian workers, trying to outline their reasons for migration to certain destinations and not to others.

Various factors are seen as underlying forces of migration. The economic drivers of all migration are often divided into push and pull factors, the so-called "push-and-push model". 'This identifies a number of negative (push) factors in the country of origin that cause people to move away, in combination with a number of positive (pull) factors that attracts migrants to a receiving country' (Piracha and Vickerman, 2001: 10).

Pull factors are positive factors of the origin or the host countries: the geographic and cultural proximity and the comparative advantages of destination country (differences in wages or better working conditions). They are reason for people to stay in their home country or to be attracted to the receiving country. Well developed social security systems in the target countries are an important pull factor for migration. 'A slow transition speed may provoke migratory sentiments in the young,

\footnotetext{
${ }^{4}$ For detailed comments or figures regarding the Polish migration to the UK and the myth of Polish Plumbers, see Reichlova (2004: Ch.7 and 8), Portes and French (2005), ippr (2006a and 2005), Gilpin et al (2006).

${ }^{5}$ Due to the fact the governmental institution do not use standard criteria when collecting data regarding the migration from/to Romania, the national statistics could hardly be recognised/certified by the researchers from abroad.

${ }^{6}$ The migration studies are rather new on the Romanian 'scientific market': mostly with sociological background, the Romanian authors would hardly join their efforts to promote the launching of a dedicated migration centre and/or to prepare a comprehensive scientific publication, covering all areas of research. The studies of the scientists from abroad uses the few data available at the local level, maybe revealed during international academic conferences or meetings, and those communicated to the international institution by governmental bodies. Romania seems to be the sole state within the EU $25+2$ without a specialised institution to prepare/deliver specialised scientific research/education/training/publications on mobility and migration. In the framework of the Jean Monnet European Centre or Excellence within the West University of Timisoara, the authors propose the including of the migration and mobility studies [legal, economical and sociological approach] into the academic curricula at the national level and the creating of a migration centre and a dedicated web-based e-library on Romanian migration [www.migratie.ro].
} 
but a speedier transition can result in unemployment and a weak social security system can provoke mass movements' (Piracha and Vickerman, 2001: 11).

Pull factors include the fact that wages are higher in developed countries, and that there is persistent labour demand. In the UK, fertility rates are declining, the population is ageing, education levels are rising and there are increasingly negative attitudes to menialjobs among the native-born population. While the native born population appears to be increasingly reluctant to work in low paid, menial jobs, demand for low paid workers is growing (ippr 2006b: 8).

The aliens will accept to deal with 'degrading' or 'dirty' activities, because they want to gain more material resources in order to return, richer, to their home country. The low paid jobs are filled by migrants, too. They cannot afford other opportunities, and those activities are traditionally filled with immigrants [usually in the framework of the informal economy].

Push factors are negative factors pushing people out of the home country or preventing them to move into the receiving country: demographic, political and economical situation in the country of origin. 'Lower rates of population growth in the EU could lead to a significant shortfall in labour supply over the next 20 years', while 'political factors are more complex and could possibly influence the migration decision more profoundly than the democratic factors. Impatience, particularly of educated youth, with the slow speed of transition to liberalised markets and the increase in ethnic tensions within a number of CEEC which remains masked during the communist period could both emerge as major push factor' (Piracha and Vickerman, 2001: 10-11).

In the cost-benefits analysis more variables take part: the salary [wage] differences among different countries; differences in unemployment rates; the grade of social protection (social policies); an assembly of costs related to migration (information costs, transportation costs, costs of installation in a foreign country, psychological costs related with the moving off the birth place, the networking costs). The data show that migration rate is lowering as the medium income in the host countries grows up and the medium level of income in the origin country begins to lower and the migration costs begin to grow. Schiff (2006) adds financial constraints to migration costs as relevant features for migration. Migration costs include moving costs, cost of searching for a job and of housing and sustenance until a job is found, the time and money cost of obtaining a passport and visas, and payments to intermediaries in case of illegal migration. 'Assuming the ability to pay for migration as binding constraint, with heterogeneous migration costs, trade liberalisation in the source country that raises the country's wage rate enables more people to pay for migration, resulting a greater migration rate' (Schiff 2006: 9-10). For the larger developing countries, where the transport costs are higher, migration costs may constitute a barrier to migration. From informal interviews at the Romanian border with illegal immigrants from China, some years ago, we noted the specificity of Chinese migration to Europe: the whole family pays for the costs of a member's migration $^{7}$. As soon as finds a job, the Chinese migrant starts payments back home to return the loans to his relatives. The costs to migrate to Europe could rise up to 20-30,000 USD.

As previously stated, the economic conditions at home influence the chances of someone migrating. 'In poorer regions, potential migrants are less able to carry the costs of migration' (Krieger 2004: 83). The unskilled individuals are constrained by their ability to pay for migration costs, while the skilled individuals can pay for migration and is able to choose between remaining in the source country or migrating, as depending on the equilibrium between the benefit from migration and the migration costs (Schiff 2006:12). A reduction in international migration costs implies an increase in skilled labour incentive to migrate and unskilled migrants to pay for migration costs, both types of labour mobility increase. As soon as the globalisation and trade without restrictions reduced the costs of transportation, migration increased in the same time with the increased incentive to leave home back of poorer or low-skilled would-be emigrants. Longdistance transportation and communication are within the reach of even relatively poor people now.

\footnotetext{
${ }^{7}$ For other examples regarding the results of empirical studies at the Romanian border between 1998-2002, see Simina (2002)
} 
Flying a low cost air company it is not a fortune at all in the last period, and migrants could travel easily between the host country and the country of origin. Some companies already flies from Romania carrying economic migrants, in their attempt to connect Romania on the other part of the European Union [the 'open sky' agreement allows all European air companies to enter Romanian space without legal constraints ${ }^{8}$ ]. BlueAir [Romanian], Skyeurope [Czech], MyAir [Italian], Wizzair [Hungarian/Polish] and easyjet [British] are names of low-cost air transport companies very known by all categories of Romanian migrants. In the case of Romanian emigration after the moment the European Union Member States decided to lift the binding tourist visa [2002], the competition between the Romanian bus companies lowered the price of transportation to destination country of choice. In this way, 'waves' of Romanians decided easily to travel abroad for work (even working in irregular conditions), due to the fact that the migration costs decreased. As soon as some member of the families arrived in a certain place, they informed and helped the other members of the family or local community to take the decision to migrate. The better developed networks of migrants from their area of origin, the lower the costs and risks of migration, and higher the probability of migration into a certain area. Sandu (2000a and 2000b), Sandu et al (2004), Constantinescu (2003), Şerban and Grigoraş (2000) and Potot (2000) provide extensive analyses of Romanian circulatory migration phenomena and the formation networking process within Romania and European Union ${ }^{9}$, while Agunias (2006) review the international literature on circular migration.

From the perspective of the 'new' economy of migration, migrations are a result of collective decision [household decision] in the background of incertitude situations and market imperfections. The economy of the immigration vary by time and place, and immigration can be either beneficial or harmful (Borjas 1999: 1). Households accept diverse risks to their economic well-being by specific allocation strategies of labour within the family. Some family members are engaged in economic activities in the local community, often the head of household or the younger men is sent abroad to foreign labour markets with better employment conditions and higher wages.

The equilibrium wage on a regional labour market is driven by labour supply and labour demand. According to the labour market dualism, the migrations are explained by the labour force need originating from host organization (enterprises). 'Migration is in the first instance caused by geographical differences in labour supply and demand' (Krieger 2004: 82). The higher the expected reduction of relative income deprivation related to the area of origin through migration, the higher the intention for migration.

Based on this theory, the salary hierarchies represent the prestige hierarchies ${ }^{10}$. Employers in EU countries may also face a general motivational problem to fill unattractive jobs at the bottom of the occupational hierarchy by local workers, as they are combined with a low societal status. Hence, employers may decide to look for employees, e.g. in the acceding and candidate countries, who have fewer considerations regarding status and prestige in their destination country. The aliens accept to deal with 'degrading' activities because they want to gain more material resources in order to return, richer, to their home country. 'This attitude of migrant workers is supported by relative deprivation, where the perception of the migrant is not determined by reference groups in the host country but solely by its status and well-being in the home country. A low status job in a receiving country may be a high status job in the country of origin' (Krieger 2004: 86-87).

Demographic pressure (lower rate of population growth in the EU), wars, persecutions [political climate, among other types of persecutions] and environmental catastrophes [connected to economy crises that may follow the catastrophes] could be mentioned as important drivers for migration for both voluntary and forced migration (i.e. refugee, asylum seekers). Other theories allocate migrations to socio-historical factors: i.e. the final destinations of the labour force

\footnotetext{
${ }^{8}$ The ECAA Agreement (20 December 2005) COM(2006) 113 final - 2006/0036 (CNS) ensures open access to air routes within the ECAA for any ECAA Air Carrier. For detailed information regarding the European Common Aviation Area and the developments on the agenda of the European Union air transportation policy, see the European Commission DG Energy and Transport web page: http://ec.europa.eu/transport/air_portal/international/pillars/common_aviation_area/ecaa_en.htm.

${ }^{9}$ For more papers on circular migration of Prof. Dumitru Sandu from Bucharest University, please visit his on-line library at: $\mathrm{http}: / /$ dumitru.sandu.googlepages.com. We present our opinion on networking and the network effect of migration further on

${ }^{10}$ Analyse of Romanian migration further on is based on a research done using the well-known Maslow's theory of basic needs.
} 
migration are countries with a rich historical background ${ }^{11}$. While economic push and pull factors are central to decisions to migrate, it is essential that social and political factors are considered' (ippr 2006b: 8). Political factors are more complex and could influence the migration decision more profoundly than the demographic factors (Piracha and Vickerman 2001: 11). The environmental factors are rather new on the migration agenda. Peter van Krieken (2004) mentions economics/ecology, war, persecution/repression and demography as causes for migratory movements: 'these four main causes are interrelated: war has an impact on the economy; demographic developments may have an impact on the ecological balance, and so on'. In the same way, the migratory movements can also be the cause of problems like war, social repression, economic gap, demographic awareness: migratory movements primary become elements for an increasingly conflicting situation when there is a lack of integration of immigrants and migration policies (van Krieken 2004). And of course lack of education regarding acceptance of immigrants (mentality).

We consider that the economic factors are most significant push factors. The migration behaviour based on neo-classical labour market theory put great emphasis on income and income differentials as the main motivation for migration. In our research we emphasise the importance of personal needs and expectations on the decision to migrate. We agree that the differences in wage between the origin and the country of choice put a great pressure on the households, but the gap between the income earned in the country of origin and the sum that could be obtained abroad it is not sufficient to leave your home and family/children back. Usually the migration's costs increase by adding the psychological costs of putting back family, social networks and position into the [local] society/community. There are many other variables to be taken into account when analysing the migration decision, and we consider that the economic theory based income differences should be improved. If the would-be emigrant manage to surpass his basic needs and is motivated by the fulfilling of the esteem-related needs, he/she easily decide to migrate. 'Majority of EU citizens is probably able to fulfil their physiological needs and feel safe within their current place of residence. Hence these reasons are no more the driving force of mobility as in past times when people moved to feed their family and escape from uncertain places and countries. We can say that extensive social security lowers motivation for migration' (Reichlová 2004: 42).

Among other authors, ippr (2006a and 2006b) did independent analyses of the likely impact of Bulgarian and Romanian accession to the EU, paying particular attention to past enlargement experiences and examining the drivers for migration this time round. We used the Abraham Maslow's motivational theory to construct the argument for our theory: the need for esteem is probably most important for a big part of the Romanians who continue to migrate to the EU, especially for those going to Italy and Spain. Analysing the fourth scale of the "motivation pyramid', Reichlová (2005) suggests that 'people will move if this step is followed by improved social status or attainment of fame' (Reichlová 2005: 9). And this is not a reason to induce mass migration (Romanians are not as poor as they are pictured in some European [tabloid] media or in much of academic papers wrote using only data from curt statistics). It is true that there are Romanians for whom labour mobility [as mentioned above, after 2007 it's wrong to say 'migration' for Romanians] constitutes an escape from a poor situation. Maybe some scientists do not agree with us, but these poor workers could find jobs in Romania if they really wish and look for [of course, maybe with a lower salary that its expectations and/or maybe in other field, needing to acquire some new abilities or to change the profession]. At mid October 2006, the National Agency for Occupation of Labour Force and Vocational Training (within the Ministry of Labour, Social Solidarity and Family) was looking for some 10,000 people $^{12}$ : Romania needs at least some 10,000 people to fill the gap on the labour market; Romania needs people, not working places! With other words, those 10,000 people who are missing were not migrated because they didn't find work. We

\footnotetext{
${ }^{11}$ Spain and Italy were a major reservoir for the European migration between the 1950s and the 1980s. Nowadays, Romanians mostly migrate to Italy and Spain.

${ }^{12}$ Romania, on the threshold of the lack of workers crisis, as wrote on HotNews.ro (17/10/2006). See Box no.2 above for more headlines in the Romanian press on the crisis on the labour market.
} 
should determine other reasons that drive Romanian migration, apart from the inequality in wages and shortages in labour on the local labour market.

As Maslow mentions, 'we have what we may call the desire for reputation or prestige (defining it as respect or esteem from other people), status, fame and glory, dominance, recognition, attention, importance, dignity, or appreciation. [...] Satisfaction of the self-esteem need leads to feelings of self-confidence, worth, strength, capability, and adequacy, of being useful and necessary in the world. But thwarting of these needs produces feelings of inferiority, of weakness, and of helplessness ${ }^{13}$. The model of Reichlová (2005) which try to find if the theory of motivation can explain the decision to migrate,

'reflects the fact known and recognized by psychologists but scarcely used in economics.
That is general preference for known, familiar and predictable environment. In case of
migration we can express this psychological phenomenon as general preference of living
in native country compared to life abroad. In comparison with other migration models we
are able to explicitly work with preference for known, familiar environment and
appreciation of proximity of friends, family and other socially tied individuals. These
factors are in majority of models hidden under the all inclusive term "barriers".' Reichlová (2005: 21)

When we discussed the distortions on the Romanian labour market, we presented our opinion related to the fact that Romanian workers migration should not be compared with the Polish case in terms of destinations, flows and tendencies. The media influenced the previsions that suggest that Romanians will target UK as destination country after 2007, because the Polish did so soon after 2004. It is true that there are similarities among the labour flows from Romania and Poland, namely the age group, the unemployment rate in the source region, the average education/skilled individuals. But the language and the network effect of migration show that Romanians will be mainly attracted by the same destination countries, Italy and Spain, even if some of them will go to Britain (having in mind the labour stock of the countries is at a very low level, there are no migrants for a mass influx to UK, we believe that the migrants who will chose UK are those with former migration experiences and possible migrants that are already abroad at the time of accession and change their position within the labour market, moving from South-Eastern Europe to the UK). We launch the debate on the following subject: UK does not fear of Romanians, it rather needs Romanians and use media debate to attract the interest of the labour workers! Maybe the facts could show something else, but we would like to emphasise some specificities of migration to Britain. From our empirical research at the borders (see Simina 2002), we know that even before 2002 Romanians entered UK, staying there with irregular status ${ }^{14}$ [overstaying the tourist visa and quite often entering with false passports, usually Portuguese: nobody heard Portuguese or Romanian in the UK before, so nobody was able to easily recognise a Latin language which is neither Italian, nor French or Spanish, but sometimes similar, as sounds strange Latin. Showing the false Portuguese passports, the Romanians were allowed to enter the country and then the labour market freely]. With other words, those who embraced the idea of living and working in the UK are already there, they don't need to wait for the Romania's accession to the EU to do this. We would underline our opinion: it is generally felt that that the majority of Romanians inclined to work

\footnotetext{
${ }^{13}$ The text of Abraham (Harold) Maslow could be found easily in the virtual spaces, many web pages including excerpts of his famed theory, originally published as: Maslow, Abraham H. (1943): A Theory of Human Motivation, in Psychological Review, 50, 370-396. It was revised and updated with very little change when it was included in his 1954 book, Motivation and Personality, and again in the $4^{\text {th }}$ chapter of the 1970 second edition as: Maslow, Abraham H. (1970): Motivation and Personality, 2nd. ed., New York: Harper \& Row. The source of the text we used is: http://www.xenodochy.org/ex/lists/maslow.html. We cannot guaranty for its accuracy, we only used it to picture our ideas.

${ }^{14}$ According to ippr (2006b: 10), Romanians were the fourth largest European nationality group in detention, after Turkish, Serbians and from Montenegro. Analysing the irregular status of Romanians, one should have in mind the fact that as starting with January $1^{\text {st }}$ 2007, when Romania joins the EU, the Romanian citizens could be irregular workers, but they cannot have irregular presence on the UK territory, regardless the ways of entrance and the period of journey.
} 
outside of Romania are already doing so. As emphasised above, there are many reasons for migration, but the accession is not among them!

As a response to the media debate regarding Romania's emigration, we consider the reasons why Romanians do not face mass migration to the UK. We do not say the Romanians will not go to UK any more, but we consider that the first choice will be countries as Spain, Italy and maybe France (see Figures 1 a-c presenting the inflows of top 10 nationalities as a percent of total inflows of foreigners in Italy and Spain). In a study which relates the intention to move into the another European country to the total population of each accession county (in the framework of the quality of life in Europe), the European Foundation for the Implement of Living and Working Conditions, Dublin, found that 52.8\% Romanians and Bulgarians expressed their willingness to live in another European country where the language is different from mother tongue as "not at all". All researchers agree that Italian, Spanish and French are more related to the Romanian (the mother tongue of Romanians) than English which is spoken in the United Kingdom.

Figure 1a ITALY: Inflows of top 10 nationalities as a \% of total inflows of foreigners

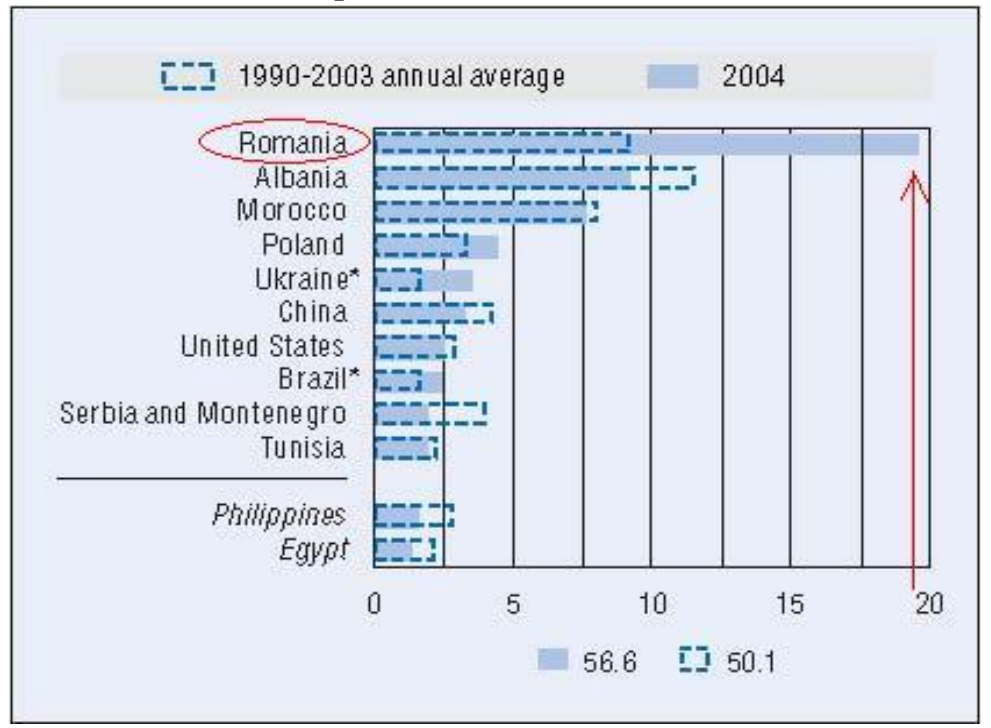

Source: OECD 2006: 191, Statlink: http://dx.doi.org/10.1786/663488602457

Figure 1b SPAIN: Inflows of top 10 nationalities as a $\%$ of total inflows of foreigners

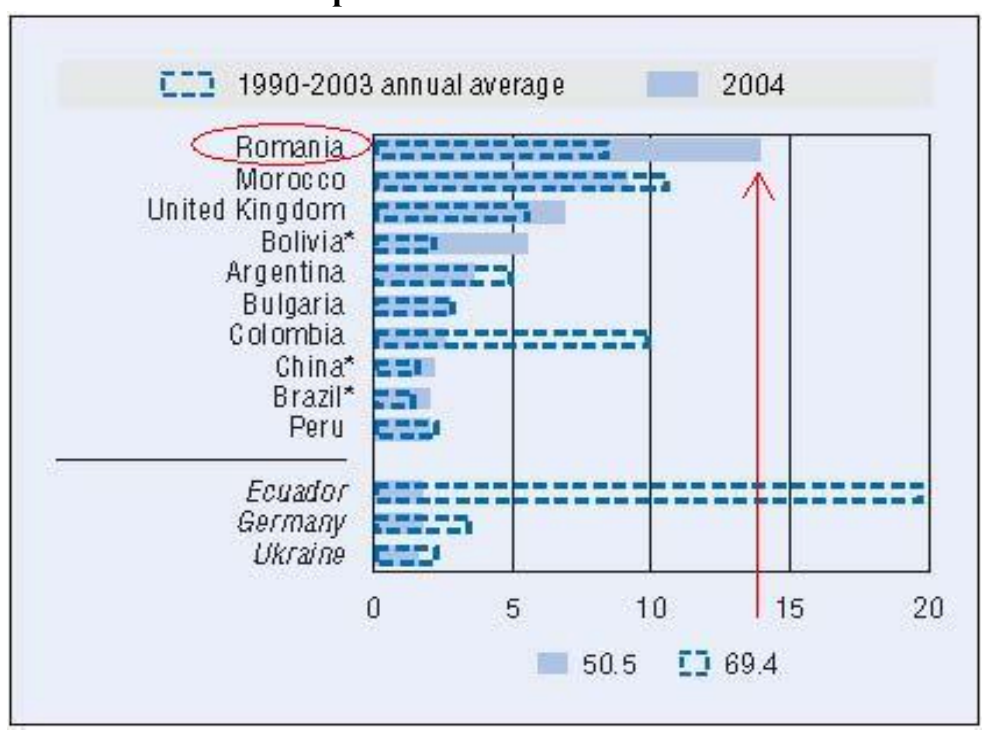

Source: OECD 2006: 215, Statlink: http://dx.doi.org/10.1786/125324665132 
Figure 1c SPAIN: Inflows of foreign population by nationality

Thousands

\begin{tabular}{lrrrrrrr}
\hline & 1998 & 1999 & 2000 & 2001 & 2002 & 2003 & 55.0 \\
\hline Romania & 0.5 & 1.8 & 17.5 & 23.3 & 48.3 & 40.5 \\
Morocco & 10.6 & 14.9 & 38.3 & 39.5 & 40.2 & 40.9 & 58.8 \\
United Kingdom & 4.5 & 7.9 & 10.9 & 16.0 & 25.3 & 32.1 & 44.3 \\
Bolivia & 0.2 & 0.5 & 3.3 & 4.9 & 10.6 & 18.1 & 35.3 \\
Argentina & 1.2 & 1.9 & 6.7 & 16.0 & 35.4 & 24.8 & 23.2 \\
Bulgaria & 0.2 & 0.7 & 6.5 & 11.8 & 15.9 & 13.6 & 17.9 \\
Colombia & 2.3 & 7.5 & 46.1 & 71.2 & 34.2 & 10.9 & 16.6 \\
China & 1.0 & 1.6 & 4.8 & 5.2 & 5.7 & 7.3 & 14.4 \\
Brazil & 0.9 & 1.6 & 4.1 & 4.3 & 4.7 & 7.3 & 13.0 \\
Peru & 2.1 & 2.9 & 6.0 & 7.1 & 8.0 & 13.3 & 13.0 \\
Ecuador & 2.0 & 9.0 & 91.1 & 82.6 & 89.0 & 72.6 & 11.9 \\
Germany & 7.1 & 9.3 & 10.2 & 10.7 & 11.2 & 11.1 & 11.8 \\
Ukraine & 0.2 & 0.6 & 6.3 & 11.0 & 10.8 & 9.1 & 10.3 \\
Venezuela & 0.9 & 1.6 & 3.4 & 4.1 & 5.4 & 10.4 & 10.2 \\
Uruguay & 0.2 & 0.4 & 1.3 & 2.8 & 6.2 & 9.3 & 9.8 \\
Other countries & 23.4 & 37.0 & 74.3 & 83.5 & 92.2 & 93.7 & 265.7 \\
Total & $\mathbf{5 7 . 2}$ & $\mathbf{9 9 . 1}$ & $\mathbf{3 3 0 . 9}$ & $\mathbf{3 9 4 . 0}$ & $\mathbf{4 4 3 . 1}$ & $\mathbf{4 2 9 . 5}$ & $\mathbf{6 4 5 . 8}$ \\
\hline & & & & & &
\end{tabular}

Figure 2 Countries where those with intentions to leave would like to work (\%)

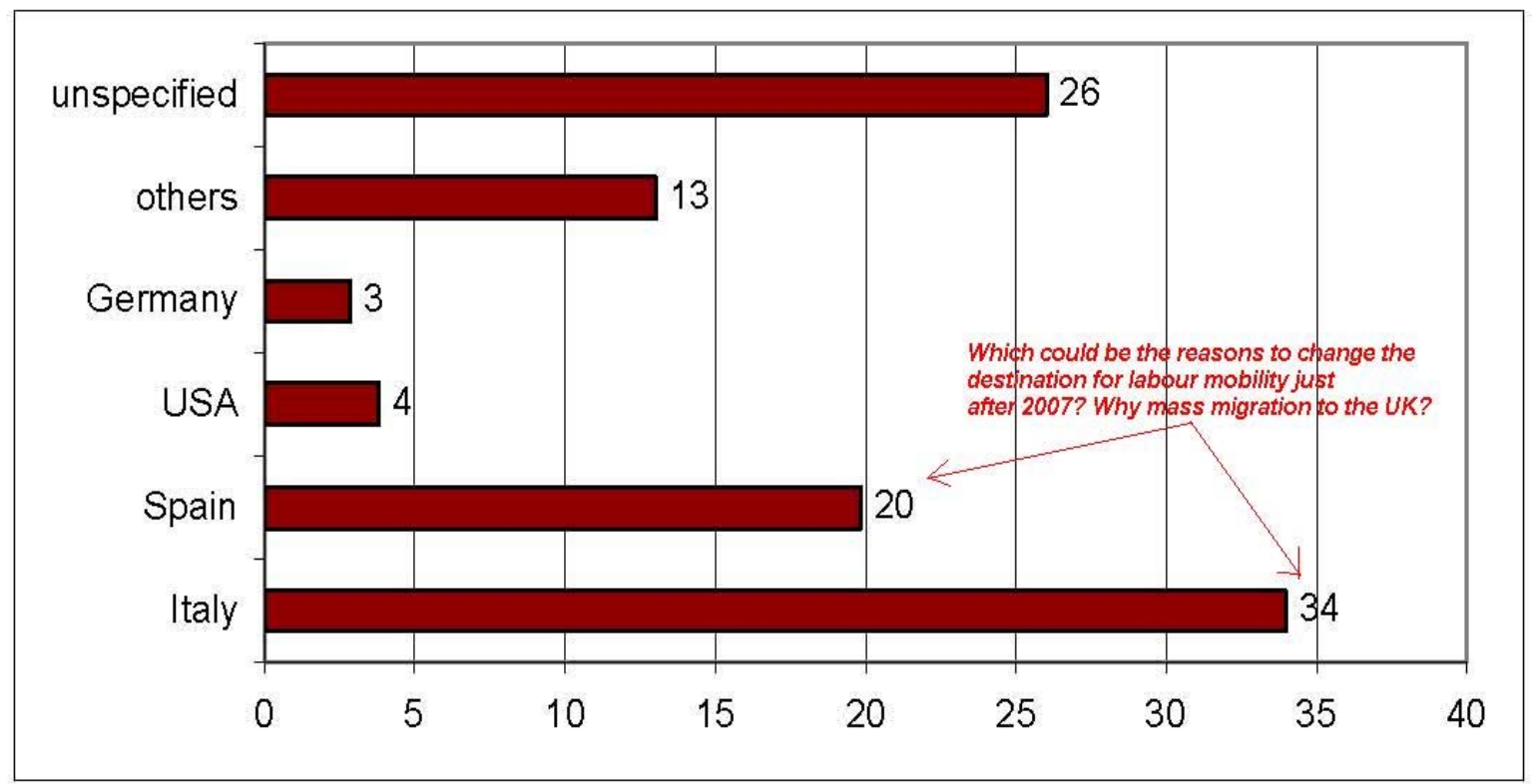

Source: FSD (2006), Figure 8, page 31. Countries where those with intentions to leave would like to work (\%)

Data source: TLA Survey, basic sample, subsample of people with intention to leave to work abroad. N=106. Example of reading: $20 \%$ of the people aged 18 to 59, who would like to leave abroad to work, within the following year, target Spain as place of destination

If we relate to Maslow's theory, the research conducted by the Romanian National Association of Citizens Advice Bureaux revealed that the reason most often put forward was the NEED FOR ESTEEM (the fourth level/step), that means $75 \%$ of the respondents (Figure 3). The questionnaire: the reasons why peoples from Romania [who worked/is currently working in the EU] have migrated 
to the EU for work (759 respondents). The 'need for esteem' is a superior reason for migration, that means the emigrant had already satisfied the other needs (levels I, II and III) in Romania, before the migration decision and/or migration itself (ANBCC 2005).

Figure 3 Emigration reasons - Abraham Maslow's scale
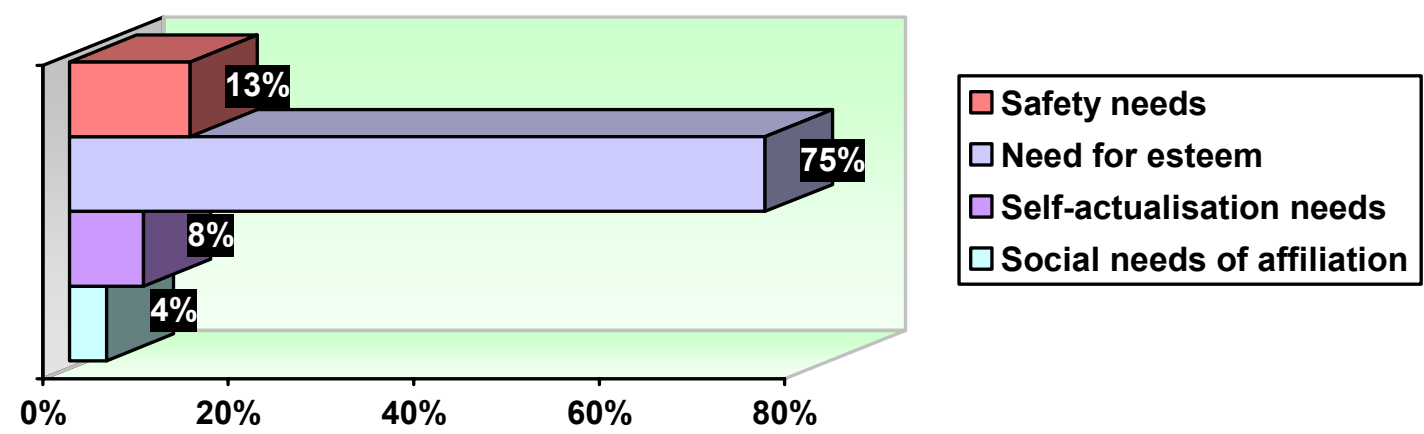

Source: ANBCC (2005: 13)

The first situation is when physiological needs are not grated. Then the only desire is to achieve additional sources of nourishment. Individual will move into another location provided that this step decreases hunger or thirst. Second, the individual has enough food but lives in unsafe, threatening surroundings where his life is endangered or the environment is chaotic and unpredictable. Then he or she will move to another location if the level of safety, predictability and order grows through such a step. Nevertheless, this move will not be done if the new safe place does not provide enough sources to guarantee gratification of physiological needs. On the other hand, safety needs are an important factor binding people to their native land. The territory they are living in is familiar, majority of people they are dealing with are known, they have social status that is connected with some duties and rights, they can communicate with other people using their native language, they are well oriented in cultural customs and they know their rights and acceptable ways of behaviour. Unfamiliar and sometimes hostile environment in destination country disturbs safety and stability requirement and thus decreases benefit from migration. Reichlová (2005: 9)

\section{The South-Eastern Europe Syndrome}

With the "South-Eastern Europe Syndrome", we analyse the fact that the Romania develops in the same way like the southern countries which joined the EU in previous waves of enlargement. The EU has no reasons to fear Romania maintains its undeveloped economy. During the transition of Romania, all economic mechanism suffered strong structural crisis: Romania had a very powerful industry sector and a cooperative based agriculture, with workers trained for steel industry and mechanized agriculture. After the failing of the communist regime, the industrial companies were privatized and than closed, the land was returned to the farmers and the cooperative farms were destroyed. Romanians were prepared for an industry based productive economy, nowadays Romania is the land of the service industry, with investments in banks, distribution and selling industry. Soon after the changing of the regime, Romania met large unemployment and lot of 
people in need of identity. A solution: emigration for labour. Most of the former industrial areas are now transformed in investments for the real estate market. The agricultural land is used for developing large real estate projects. All major European retailers are 'landed' on the Romanian distribution market, with huge hypermarkets and entertainment areas [even considered the capital city of a 'poor country', with low income, a Bucharest based hypermarket of Carrefour is the third in the world as counting the transit of customers during the Christmas holidays, whit more than 100,000 people visiting the site per day]. In the same time, alike in countries as Spain and Portugal before their accession to the EU, lots of investors have bought plenty of land and buildings, for speculation on the real estate market purposes (the price of real estate multiplied many times, as compared to the price just before the accession). The same situation is met mostly in western Romania, but even in Constanța county, south-eastern region: Italians and Greeks have bought almost all available agricultural and in-town land, with the purpose of eventually reselling it upon the Romania's accession to the EU. Nowadays, Spain is one of the main receiving countries of older emigrants in Europe, the main destination for European retirees (mainly thanks to its tourist tradition), due to the economic attraction of tourism factors (pensions, expenses at the place of destination). In the same time, the economy is growing. Before the EU: the Spain workers have migrated to the north of Europe for jobs, while the capital moved to Spain as investments in land and real estate. After the accession: Spain, Portugal and southern Italy benefited from the financial aid of the EU. Spain launched policies to help the families to raise the birth rate (the demographic growth), attracting immigrants with regularisation measures.

Those migrants supported the Spain economic development. The same situation is met in Romania, but using the "fast forward" style. We already need workers!

\section{References}

ANBCC (2005), Romanians and Labour Force Migration in the European Union, Romanian National Association of Citizens Advice Bureaux, Bucharest, December

Agunias, Dovelyn Rannveig (2006): From a Zero-Sum to a Win-Win Scenario? Literature Review on Circular Migration, Migration Policy Institute, Migration Information Source, September, available from www.migrationpolicy.org/pubs/CircularMigrationLitReview_9.06_DAgunias.pdf

Borjas, George J. (1999): Immigration, National Bureau of Economic Research, NBER Research Summary, Fall; retrieved from (18.09.2005): www.nber.org/reporter/archieve.html

Ciutacu, Constantin (2006): Growing Concern over Labour Shortage Due to Migration, European Foundation for the Improvement of Living and Working Conditions, Dublin, available at (29.11.2006): www.eurofound.europa.eu/eiro/2006/11/articles/ro0611049i.html

Constantin, Daniela Luminița et al (2004): The Migration Phenomenon from the Perspective of Romania's Accession to the European Union, Pre-Accession Impact Studies II, Study no.5, Bucharest: The European Institute of Romania 
Constantinescu, Monica (2003): International Circular Migration to Spain - A Case Study, conference paper at "Globalization, Integration and Social Development in Central and Eastern Europe. A Round Table for Young Social Scientist from CEE Region”, Lucian Blaga University of Sibiu, Romania, 6-8 September 2003, retrieved from:

www.iccv.ro/romana/conf/conf.sibiu.2003/pdf/18.\%20monica\%20constantinescu.pdf

ECAS (2006a): Report on the Free Movement of Workers in EU-25: The Functional Arrangement Two Years after Enlargement", Brussels: European Citizen Action Service, July

ECAS (2006b): Report on the Free Movement of Workers in EU-25: Who's Still Afraid of EU Enlargement, European Citizen Action Service, October

ECAS (2005): Report on the Free Movement of Workers in EU-25: Who's Afraid of EU Enlargement?, European Citizen Action Service, September

FSD (2006): Living Abroad on a Temporary Basis. The Economic Migration of Romanians: 19902006, Sandu, Dumitru (co-ordinator), Fundația pentru o Societate Deschisă (Open Society Foundation), Bucharest, November

Ghosh, Bimal (2005): Economic Effects of International Migration: A Synoptic Overview, in World Migration 2005. Costs and Benefits of International Migration, Volume 3 - IOM World Migration Report Series, Geneva: International Organisation for Migration, pp.163-183

Gilpin, Nicola et al (2006): The Impact of Free Movement of Workers from Central and Eastern Europe on the UK Labour Market, Department for Work and Pensions, Working Papers No.29

ippr (2006a): EU Enlargement: Bulgaria and Romania - Migration Implication for the UK, Institute for Public Research, ippr FactFile, April 25

ippr (2006b): Irregular Migration in the UK, Institute for Public Research, ippr FactFile, March 31

ippr (2005): Selecting Wisely: Making managed migration work for Britain, Institute for Public Research, November 27

Krieger, Hubert (2005): Who Is Going Where? Migration Trends in the EU Context, European Foundation for the Improvement of Living and Working Conditions, Dublin, April; conference paper at SIPTU National Women's Forum, Tralee, 22-24 April 2005, available from: www.eurofound.europa.eu/docs/areas/populationandsociety/Kriegen05042.pdf

Krieger, Hubert (2004): Migration Trends In An Enlarged Europe, European Foundation for the Improvement of Living and Working Conditions, Dublin, 2004 - VIII, Luxembourg: Office for Official Publications of the European Communities, EF/03/109/EN, available from:

Maddison, Angus (2002): The West and the Rest in the International Economic Order, OECD Observer, no. 235, Paris: OECD

MMSSF (2006): Evolution of Occupations on Romanian Labour Market in 2010 Perspective, coordinated by Speranța Pîrciog, Vasile Ciucă and Eugen Blaga, Ministry of Labour, Social Solidarity and Family, Bucharest

OECD (2006): International Migration Outlook. Annual Report [Sopemi] 2006 Edition, Paris: Organisation for Economic Co-operation and Development; retrieved from link http://www.sourceoecd.org/926403627X

Piracha, Matloob and Roger Vickerman (2001): Immigration, Labour Mobility and EU Enlargement, ESRC One Europe or several? Programme: Borders, Migration and Labour Market Dynamics in Europe, UK Economic and Social Research Council, Grant No L213252042, available at: www.kent.ac.uk/economics/research/1 europe/RIIAChapter-final.pdf

Portes, Jonathan and Simon French (2005): The Impact of Free Movement of Workers from Central and Eastern Europe on the UK Labour Market: Early Evidence, Department for Work and Pensions Working Papers No.18, London: Department for Work and Pensions

Potot, Swanie (2000): Mobilité en Europe. Etude de Deux Réseaux Migratoires Roumains, in Sociologie Romanească [Romanian Sociology] 2, pp. 97-115 [in French], retrieved from www.sociologieromaneasc.ro/2000/articole/sr2000.2-a5.pdf

Reichlová, Natálie (2005): Can the Theory of Motivation Explain Migration Decisions?, Charles University Prague, Faculty of Social Sciences, Institute of Economic Studies, IES Working Papers UK FSV-IES No.97, Prague, retrieved from (20.10.2006) 
http://ies.fsv.cuni.cz/storage/publication/686_wp_97_reichlova.pdf

Reichlová, Natálie (2004): New Member Countries and Migration Flows, Diplomová Práce [Master thesis], Univerzita Karlova v Praze, Fakulta sociálních ved, Institut ekonomických studií, retrieved from (12.11.2006) http://ies.fsv.cuni.cz/storage/user/121_reichlova-dp.pdf

Sandu, Dumitru et al (2004): A Country Report of Romanian Migration Abroad: Stocks and Flows after 1989, Multicultural Centre Prague, migrationonline.cz, retrieved from: http://aa.ecn.cz/img_upload/f76c21488a048c95bc0a5f12deece153/RomanianMigrationAbroad. pdf

Sandu, Dumitru (2000a): Migrația circulatorie ca strategie de viață, in Sociologie Românească 2, pp.5-29 [in Romanian], available from:

www.sociologieromaneasca.ro/2000/articole/sr2000.2-a1.pdf. English version available as Circulatory Migration as Life Strategy, in Sociologie Românească / Romanian Sociology Annual English Electronic Edition - issue 2 (2000), from:

www.sociologieromaneasca.ro/eng/aeee-pdf/sr-rs.aeee.2000.5.pdf

Sandu, Dumitru (2000b): Migrația transnațională a românilor din perspectiva unui recesământ comunitar [The Romanian Transnational Migration from the Perspective of a Communitary Census], in Sociologie Românească [Romanian Sociology] 3-4, pp.5-52, available on-line from: www.sociologieromaneasca.ro/2000/articole/sr2000.3+4-a1.pdf

Sandu, Dumitru (1985): Fluxurile de migrație în România [Migratory Flows in Romania], Bucharest: Editura Academiei; [in Romanian] available on-line from:

http://193.231.1.3/mod/resource/view.php?id=334\&subdir=/Fluxurile_de_migratie_in_Romania

Schiff, Maurice (2006): Migration, Trade and Investment: Complements or Substitutes?, Centre for International Studies on Economic Growth, CEIS Tor Vergata Research Paper Series, Vol.30, No.89, November; available at: http://pappers.ssrn.com/paper.taf?abstract_id=944458

Silaşi, Grigore et al (2005): Migration and Foreign Direct Investments: Substitutes or Complements?, West University of Timisoara, Jean Monnet European Centre of Excellence, SISEC Discussion Papers vol.2 No.9, December

Simina, Ovidiu Laurian (2002): Romania - Source Country and Transit Country for International Migration, UNU/WIDER Conference on Poverty, International Migration and Asylum, Helsinki, September; www.wider.unu.edu/conference/conference-2002-3/conference20023.htm, published as SISEC Discussion Papers vol.1 no.1, October 2002, West University of Timisoara

Strielkowski, Wadim and Cathal O'Donoghue (2004): The Impact of the EU accession on international labour migration, Charles University, Faculty of Social Sciences, Institute of Economic Studies, Jean Monnet Workshop, Prague, September; retrieved from (12.10.2006) http://ies.fsv.cuni.cz/storage/user/117 jmw2004phdr.wadimstrielkowskipaper.pdf

Şerban, Monica and Vlad Grigoraş (2000): The „Dogenii” from Teleorman in Romania and Abroad. A Study on Circular Migration to Spain, in Sociologie Românească/Romanian Sociology - Annual English Electronic Edition - Issue 2 (2000), available on line from http://www.sociologieromaneasca.ro/eng/aeee-pdf/sr-rs.aeee.2000.5.pdf

van Krieken, Peter J. (2005): A Shoe Factory and Migratory Movement in Eleven Paragraphs, in Pop, L. and C. Matiuta (eds.): European Identity and Free Movement of Persons, University of Oradea Publishing House, 2005, pp 112-118

van Krieken, Peter J. (2004): A need to reinvent the wheel?, European Population Forum 2004, Geneva, February $12-14$, retrieve from (15.07.2005): http://www.unece.org/ead/pau/epf/present/ts4/vankrieken.pdf

Whittal, Michael (2006): Report of Mobility Highlights Economic Benefits of Migrant Labour, European Foundation for the Improvement of Living and Working Conditions, Dublin, available at (29.10.2006): www.eurofound.europa.eu/eiro/2006/09/articles/eu0609029i.html

Zaiceva, Anzelika (2006): Reconciling the Estimates of Potential Migration into the Enlarged European Union, Institute for the Study of Labor, IZA Discussion Paper No.2519, December 
NOTES 